\title{
Effect of substance use on condom use in the Theory of Planned Behavior: Analysis of differential item functioning
}

\author{
Ricardo Sánchez-Domínguez,, ${ }^{1,2}$ Luis Villalobos-Gallegos, ${ }^{1}$ Violeta Felix-Romero, ${ }^{2}$ \\ Silvia Morales-Chainé, ${ }^{2}$ Rodrigo Marín-Navarrete ${ }^{1}$
}

\footnotetext{
1 Unidad de Ensayos Clínicos, Subdirección de Investigaciones Clínicas. Instituto Nacional de Psiquiatría Ramón de la Fuente Muñiz.

2 Facultad de Psicología, Universidad Nacional Autónoma de México
}

Correspondence:

Luis Villalobos-Gallegos

Instituto Nacional de Psiquiatría Ramón de la Fuente Muñiz (INPRFM), Unidad de Ensayos Clínicos en Adicciones y Salud Mental.

Calz. México-Xochimilco 101

14370 Ciudad de México

Phone: +52 (55) 4160-5482.

E-mail: Ivillalobos@imp.edu.mx

Received first version: August 19, 2016; second version: December 15, 2016; accepted: January 3, 2017.

doi.org/10.17711/SM.0185-3325. 2017.002

\begin{abstract}
Introduction. Substance use is one of the factors associated with lower condom use in young adults, which increases the likelihood of HIV infection. The Theory of Planned Behavior (TPB) is one of the most useful models for explaining this phenomenon since it considers the aim of engaging in a behavior based on attitudes, subjective norms and self-efficacy. Objective. To develop a questionnaire and to evaluate the Differential Item Functioning (DIF) caused by substance use in TPB indicators, using the Multiple Indicators Multiple Causes Analysis (MIMIC). Method. The study was conducted in two phases with Mexico City college students age 18 to 25 . Results. Adequate goodness of fit was obtained in all three models of the TPB: attitudes $\chi_{\mathrm{s}-\mathrm{B}}^{2}(2)=3.902, p<.001 ; \mathrm{CFI}_{\mathrm{s}}=.999 ; \mathrm{TLI}_{\mathrm{s}}=.996 ; \mathrm{RMSEA}_{\mathrm{s}}=.037,90 \% \mathrm{Cl} \leq .001-.095 ;$ subjective norms $\chi_{\mathrm{s}-\mathrm{B}}^{2}(7)=9.103, p<0.245 ; \mathrm{CFI}_{\mathrm{s}}=.999 ; \mathrm{TLI}_{\mathrm{s}}=.998 ; \mathrm{RMSEA}_{\mathrm{s}}=.022,90 \% \mathrm{Cl} \leq .001-.056 ;$ and self-efficacy $\chi_{\mathrm{s}-\mathrm{B}}^{2}(25)=65.115, p<.001 ; \mathrm{CFI}_{\mathrm{s}}=.982 ; \mathrm{TLI}_{\mathrm{s}}=.974 ; \mathrm{RMSEA}_{\mathrm{s}}=.050,90 \% \mathrm{Cl}=.036-.066$; in one item in attitudes and two items in subjective norms a DIF effect was observed, while no item proved significant regarding self-efficacy. Discussion and conclusion. There is little evidence in the detection of DIF due to substance use in TPB indicators in condom use, and this is the first study to conduct this type of analysis. Items presenting DIF open the door to future research due to the importance of assessing how the indicator behaves with a population displaying a particular trait.
\end{abstract}

Keywords: Condom, substance use, attitudes, self-efficacy, subjective norms, young adults.

\section{RESUMEN}

Introducción. El consumo de sustancias es uno de los factores asociados a un menor uso de condón en jóvenes adultos, lo cual aumenta la probabilidad de contagio de VIH. La Teoría de la Conducta Planeada (TCP) es uno de los modelos más útiles para explicar este fenómeno ya que considera la intención de llevar a cabo una conducta basándose en actitudes, normas subjetivas y autoeficacia. Objetivo. Desarrollar un cuestionario y evaluar el Funcionamiento Diferencial de los Ítems (DIF) ocasionado por el consumo de sustancias en los indicadores de la TCP, utilizando el análisis Múltiples Ítems Múltiples Causas (MIMIC). Método. El estudio se llevó a cabo en dos etapas con estudiantes universitarios de 18 a 25 años de la Ciudad de México. Resultados. Se obtuvo una adecuada bondad de ajuste en los tres modelos de la TCP: actitudes $\chi_{S-B}^{2}(2)=3.902, p$ $<.001 ; \mathrm{CFI}_{\mathrm{s}}=.999 ; \mathrm{TLI}_{\mathrm{s}}=.996 ; \mathrm{RMSEA}_{\mathrm{s}}=.037,90 \%$ IC $\leq .001-.095 ;$ normas subjetivas $\mathrm{X}_{\mathrm{S}-\mathrm{B}}(7)=9.103 ; p<$ $.245 ; \mathrm{CFI}_{\mathrm{s}}=.999 ; \mathrm{TLI}_{\mathrm{s}}=.998 ; \mathrm{RMSEA}_{\mathrm{s}}=.022,90 \% \mathrm{IC} \leq .001-.056 ; y$ autoeficacia $X_{\mathrm{s}-\mathrm{B}}(25)=65.115 ; p<.001 ;$ $\mathrm{CFI}_{\mathrm{s}}=.982 ; \mathrm{TLI}_{\mathrm{s}}=.974 ; \mathrm{RMSEA}_{\mathrm{s}}=.050,90 \% \mathrm{IC}=.036-.066$; un ítem en actitudes y 2 ítems en normas subjetivas se observó un efecto DIF, y en autoeficacia ningún ítem salió significativo. Discusión y conclusión. Existe poca evidencia en la detección de DIF por uso de sustancias en los indicadores de la TCP en uso de condón, siendo éste el primer estudio que lleva a cabo este tipo de análisis. Los ítems que presenten DIF abren la puerta a futuras investigaciones, debido a la importancia de evaluar cómo se comporta el indicador con una población que tenga un rasgo en particular.

Palabras clave: Condón, consumo de sustancias, actitudes, autoeficacia, normas subjetivas, adultos jóvenes. 


\section{INTRODUCTION}

Sexually transmitted infections (STI) and HIV/AIDS continue to have a high prevalence and incidence worldwide (United Nations Programme on HIV and AIDS [UNAIDS], 2014) and in Mexico (Centro Nacional para la prevención y el control del VIH/SIDA [CENSIDA], 2016). Condoms are the prevention method that has proved to provide the best protection against the spread of STDs and HIV/AIDS, regardless of the partner's serological status (Centers for Disease Control and Prevention [CDC], 2014; United Nations Programme on HIV and AIDS [UNAIDS], 2015).

Accordingly, several theoretical models have been developed to explain condom use, with the Theory of Planned Behavior (TPB) being one of the most popular (Albarracín, Johnson, Fishbein \& Muellerleile, 2001; Andrew et al., 2016; Armitage \& Conner, 2001; Bennett \& Bozionelos, 2000; Tyson, Covey \& Rosenthal, 2014). TPB provides a conceptual framework with cognitive basis of behavior, in other words, the value an individual places on beliefs at the moment of engaging in a particular behavior (Yzer, 2012). The model suggests that behavior is determined by intention, and that the intention of using a condom is influenced by attitudes, in other words, a positive or negative evaluation of this behavior (Fishbein \& Ajzen, 1975). Subjective norms refer to the opinion of significant persons for the individual on condom use (Ajzen \& Fishbein, 1980) while self-efficacy is the perceived ability to use condoms (Ajzen, 1991), which also has direct effects on behavior.

There has been an increase in the research to measure TPB in condom use by using psychometric instruments such as the Sexual Behavior Scale (Malcolm et al., 2013), and questionnaires based on TPB (Fishbein \& Ajzen, 2010; Francis et al., 2004; Prati, Mazzoni \& Zani, 2014; Rich, Mullan, Sainsbury \& Kuczmierczyk, 2014). However, none of these instruments was specifically designed for the Spanish-speaking population.

In Mexico, very few studies have focused on developing measurement instruments that take the characteristics of the Mexican population into account other than the research by Robles-Montijo and Díaz-Loving (2011). However, this questionnaire, developed for the teenage middle- and highschool population, with a mean age of 15.38 years, found that there is a difference in the sexuality of middle-school and high school students (Vasilenko \& Lanza, 2014).

Previous studies have regarded substance use as a predictor of the determinants of the TPB in condom use, in other words, when people are intoxicated, attitudes, subjective norms and self-efficacy regarding condom use decline (Conner, Sutherland, Kennedy, Grearly \& Berry, 2008; Davis et al., 2015). However, it is not known whether the effect of alcohol use is a "true" effect or an artifact of measurement caused by the bias derived from substance use, which can be identified through the examination of Differential Item Functioning (DIF) (Starosta, Berghoff \& Earleywine, 2015).

DIF refers to the likelihood of individuals choosing a particular response on an item despite having the same degree of response to a latent variable (e.g. perceived norms of condom use). This difference in probability may be due to belonging to a particular group (for example, man/woman) or to another non-categorical variable (e.g. days of substance use) (Starosta et al., 2015).

The lack of consistency in condom use in young adults is regarded as a public health problem (Encuesta Nacional de Salud y Nutricion [ENSANUT], 2012; Instituto Nacional de las Mujeres [INMUJERES], 2012), since $58.6 \%$ of men and $75.5 \%$ of women did not use condoms (Instituto Nacional de las Mujeres [INMUJERES], 2012) during their last sexual intercourse, and reported having various sexual partners and not using condoms when they were intoxicated.

Accordingly, the valid measurement of the TPB model in condom use is a substantial need for the development and evaluation of HIV prevention programs (Noar, 2006). Given this context, this manuscript has two objectives: to develop a scale to measure the TPB model in condom use in a sample of young adults (Study 1), and to evaluate the DIF related to substance use in the questionnaire (Study 2).

\section{METHOD}

\section{Study 1}

\section{Participants}

A convenience sample consisting of 50 participants from a public university, 29 men and 21 women, with an average age of 23, who met the inclusion criteria: a) being enrolled in an academic program, and b) having over 18 and under 25 years.

\section{Measures}

The preliminary questionnaire was applied using the open question technique, and the instructions used were those proposed by Fishbein (1980): "List all the advantages/disadvantages you can think of that condom use might have" and "Mention a person(s) or group(s) you know that you think would approve/disapprove of your using a condom".

\section{Procedure}

Participants who met the inclusion criteria were invited to participate voluntarily and spend a few minutes answering a questionnaire on condoms. If they agreed to participate, they were given the open-ended questionnaire and were asked to include all the words or short sentences that came to mind and to take their time. 
Subsequently, using content analysis (Krippendorff, 1990) the information in the questionnaires was organized and the registration units (adjectives) were selected. Once selected, the repetition of the registration units was determined in the recount in order to categorize them and reduce the number of classes or categories (Krippendorff, 1990).

Once the criteria for categorizing the registration units had been obtained, the categories were coded as attitudes, norms, and self-efficacy. Adjectives evaluating condoms were placed in the attitudes category, the important people mentioned were put into the standards category and adjectives related to problems with condom use were included in the category of self-efficacy. Lastly, the items for the preliminary version of the questionnaire were drafted.

\section{Study 2}

\section{Participants}

A cross-sectional study was conducted at three universities in Mexico City using convenience sampling. Data were collected from May to August 2015. Participants were included according to the criteria in Study 1. Sample size was calculated through a previous Monte Carlo simulation study, requiring approximately 600 participants to detect a DIF with a medium effect size. The simulation was based on recommendations previously established in the literature (Muthén \& Muthén, 2002).

\section{Measures}

TPB Determinants. A 34-item instrument was used, which resulted from Study 1 (Appendix 1).

Substance use. Following the recommendation in the literature, substance use was measured through a self-report question evaluating the number of days of substance use in the previous month ("On how many of the past 30 days did you use alcohol or drugs?") (Donovan et al., 2012).

Risky sexual behavior. A self-report was used to evaluate the number of partners in the past 30 days (more than two partners in answer to the question "With how many people have you had sexual relations with anal or vaginal penetration?"), condom use during the last sexual intercourse ("Did you use a condom during your last sexual intercourse?"), knowledge of HIV sero-status of partner in the past 12 months ("How often have you known whether your sexual partner(s) was/were infected with HIV?"). These questions have been used in other studies to assess risky sexual behavior (Donenber, Emerson, Bryant, Wilson \& Weber-Shifrin, 2001).

Demographic variables. In order to describe the sample, respondents were asked about their age, sex, years of education, income and marital status.

\section{Procedure}

Five evaluators were trained to measure substance use, sexual behavior and study procedures, and were certified by a supervisor as having complied with the data collection procedures. Since most cases of HIV infection are due to sexual contact, only penile-vaginal contact was evaluated; oral sex was not evaluated. According to the recommendations of previous studies on condom use, an operational definition of a sexual intercourse was established (Crosby, Charnigo, Weathers, Caliendo \& Shrier, 2012), which was read to the participants before asking them about their sexual behavior. For the purposes of this study, a sexual intercourse was defined as "A process that begins with the insertion of the penis into the vagina or anus and ends with the male orgasm".

Participants were recruited in their respective universities by trained evaluators. Respondents who agreed to participate were evaluated to determine whether they met the inclusion criteria, and subsequently signed an informed consent form. For the purposes of analysis, cases with patterns of missing data (no response to the questionnaire regarding condom use) or who had not initiated their sexual lives were removed. All the participants included in this study gave their verbal and written consent.

\section{Statistical analysis}

Descriptive statistics are provided for demographic variables and risky sexual behavior. Differences in these variables between participants who reported at least one day of use and no day of use were estimated through the Student $t$ test for numerical variables and chi square $\left(\chi^{2}\right)$ for categorical variables.

Since the first step in undertaking a MIMIC analysis is to find a model with adequate goodness of fit, items from the version derived from Study 1 were selected. Then, a frequency analysis was conducted, the Student t test was applied for independent samples, a bias analysis was performed, and the correlation of each item (Rodríguez-Pérez, Valencia-Flores, Reyes-Lagunes \& Lara-Muñoz, 2013) with each determinant of TPB was obtained. The Exploratory Factor Analysis was replaced by the Confirmatory Factor Analysis (CFA). An unifactorial model was evaluated for each of the TPB determinants. Weighted least squares adjusted to the variance and mean was used as the estimator, since this is regarded as the most accurate estimator in CFA with non-normal Likert variables (Beauducel \& Herzberg, 2006; Muthén \& Kaplan, 1985). The fit measures that were taken into account, in keeping with the recommendations of the literature (Hu \& Bentler, 1999; Satorra \& Bentler, 2001), were the Satorra-Bentler Scaled Chi-square $\left(\chi_{\text {S-B }}^{2}\right)$, the Satorra-Bentler Scaled Chi-square between degrees of freedom $\left(\chi_{\mathrm{S}-\mathrm{B}}^{2} / \mathrm{df}\right)$, the scaled comparative fit index $\left(\mathrm{CFI}_{\mathrm{S}}\right)$, and the Scaled Root Mean Square Er- 
ror of Approximation (RMSEA $)$. Regression coefficients, standard errors and statistical significance are presented for each of the parameters estimated in the model. In order to handle missing data, the full information matrix method was used, because it has provided accurate estimates of parameters in Monte Carlo studies (Enders \& Bandalos, 2001). The next step for MIMIC was to establish similar mediation models to those established in a previous study (Miles, Marshall \& Schell, 2008), where the variable for the number of days of substance use had direct effects on each of the items and the effect was mediated by the latent variables (attitudes, subjective norms and self-efficacy) (figure 1). In this procedure, the null hypothesis is that the latent variables are complete mediators for the link, and therefore the direct effect of the variable is not significant. If the null hypothesis is rejected, DIF is assumed to exist. The MIMIC analysis was performed using the Mplus 6.12 statistical package.

Following Cribbie's recommendation (Cribbie, 2007), the deflated $p$ value associated with multiple tests was corrected through the False Discovery Rate (FDR) (Benjamini \& Hochberg, 1995) through the R 3.3.0 statistical package. A value of $p<.05$ was considered significant for all the analyses.
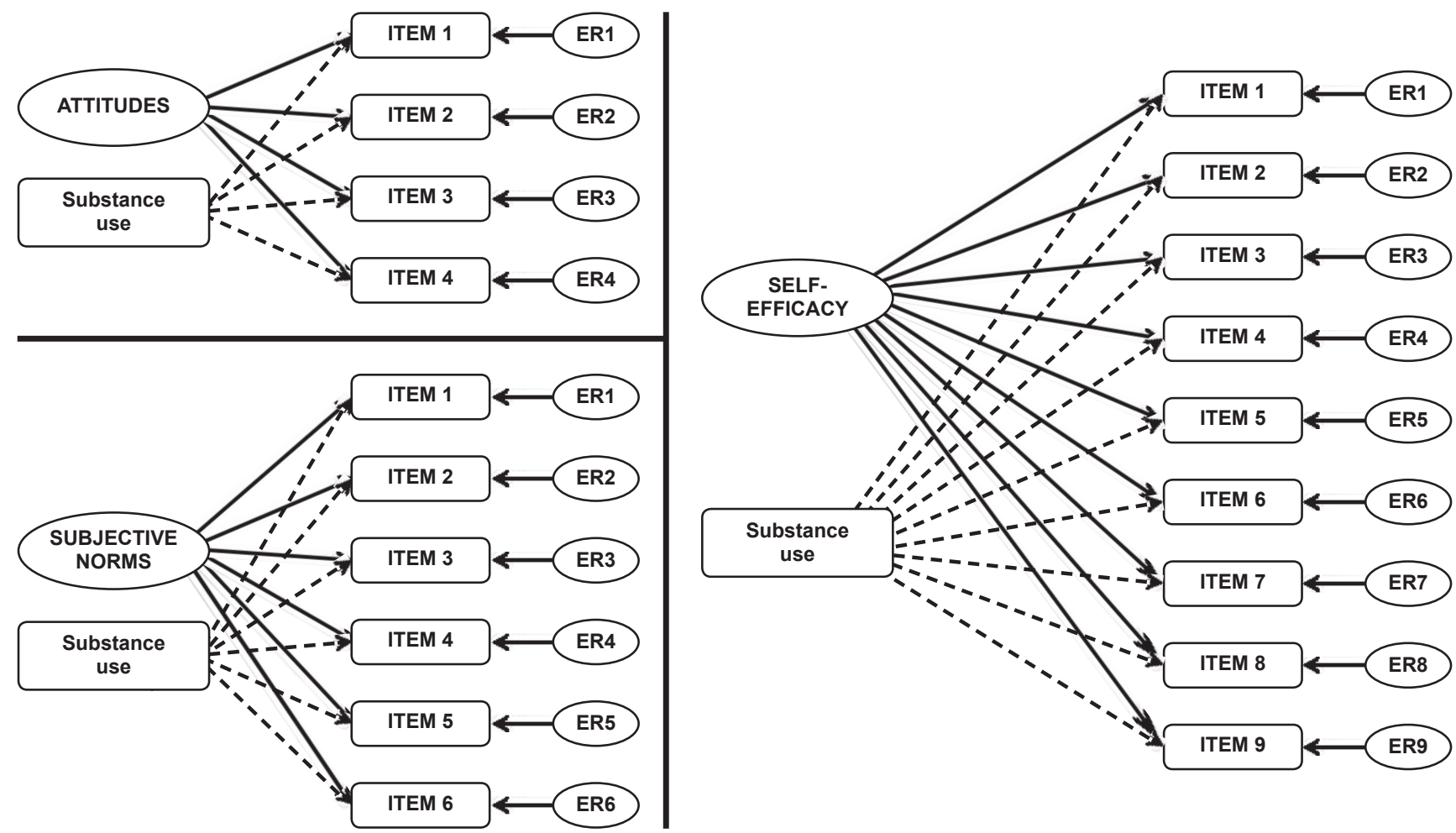

Figure 1. Graphic representation of DIF models for TPB determinants

\section{RESULTS}

\section{Study 1}

In the analysis conducted through the questionnaires with open-ended questions on condom use, the repetition of the registration units was counted for each instruction. Those with the highest frequency were chosen and the terms were categorized in the TPB dimensions (table 1).

The instrument obtained from the registration units consisted of 34 questions distributed throughout the three theoretical dimensions-attitudes, subjective norms and self-efficacy-comprising the TPB. The first dimension consisted of 10 items assessing attitudes to condom use, through a seven-point semantic differential evaluation (Pleasant-Unpleasant); the second dimension assessed subjective norms, consisting of eight items with five response choices (unimportant to very important), while the third dimension, assessing self-efficacy, comprised 16 items with five response options (totally unsafe to totally safe).

\section{Study 2}

A total of 886 university students were recruited, 697 of which initiated the application. After the eligibility evalua- 
Table 1

Responses to the open-end questionnaire

What do you believe are the advantages/disadvantages of your condom use?

\begin{tabular}{lc}
\hline Terms & Frequency \\
\hline Get them $^{\mathrm{a}}$ & 36 \\
Reduce the sensation $^{\mathrm{a}}$ & 34 \\
Pleasant $^{\mathrm{b}}$ & 32 \\
Buy them $^{\mathrm{a}}$ & 31 \\
Intelligent $^{\mathrm{b}}$ & 30 \\
Safe $^{\mathrm{b}}$ & 30 \\
Responsible $^{\mathrm{b}}$ & 28 \\
Good $^{\mathrm{b}}$ & 27 \\
Break the moment $^{\mathrm{a}}$ & 27 \\
Say "no"a $^{\mathrm{a}}$ & 27 \\
Needed $^{\mathrm{b}}$ & 26 \\
Boring $^{\mathrm{b}}$ & 26 \\
Steady partner $^{\mathrm{a}}$ & 26 \\
Forget it $^{\mathrm{a}}$ & 25 \\
Forget to use it when you are on alcohol or drugs $^{\mathrm{a}}$ & 24 \\
Difficult $^{\mathrm{b}}$ & 23 \\
Poor $^{\mathrm{b}}$ & 22 \\
Insecure to negotiate $^{\mathrm{a}}$ & 21 \\
Uncomfortable $^{\mathrm{b}}$ & 21 \\
Put them correctly $^{\mathrm{a}}$ & 20 \\
\hline
\end{tabular}

Please list the individuals or groups who would approve/disapprove or think you should condom use

\begin{tabular}{lc}
\hline Terms & Frecuencia \\
\hline Partner $^{c}$ & 45 \\
Family $^{c}$ & 38 \\
Parents $^{c}$ & 35 \\
Church $^{c}$ & 26 \\
Friends $^{c}$ & 23 \\
Physician $^{c}$ & 21 \\
Priest $^{c}$ & 17 \\
\hline
\end{tabular}

Note: a. Included in self-efficacy items; b. Included in attitudes items; c. Included in subjective norms.

tion, the sample was reduced to 646 participants (figure 2), 363 women and 279 men with an average age of 23.16 years $(\mathrm{SD}=3.19)$.

Participants had an average of 14.58 years of schooling $(\mathrm{SD}=1.16), 89.7 \%$ had never married, $6.9 \%$ were married or living together; $44 \%$ reported an approximate monthly income of between $\$ 0$ and $\$ 2000$; approximately $25.1 \%$ had a monthly income of $\$ 2001$ to $\$ 4000$, while $15.7 \%$ had an income of $\$ 4001$ to $\$ 6000$ (Mexican currency).

In relation to substance use in the previous 30 days, $75.2 \%$ reported using alcohol, $45.8 \%$ of which reported excess drinking; $13.8 \%$ used marijuana and $1.7 \%$ cocaine, while the average number of days of use was: 5.04 ( $\mathrm{SD}=$ 4.86) days of alcohol use, .72 $(\mathrm{SD}=3.51)$ of drug use and $5.62(\mathrm{SD}=5.93)$ days using any substance.

As regards risky sexual behaviors, $51.8 \%$ reported not using a condom during their last sexual intercourse, $17.1 \%$ reported several partners in the previous month, while $68.0 \%$

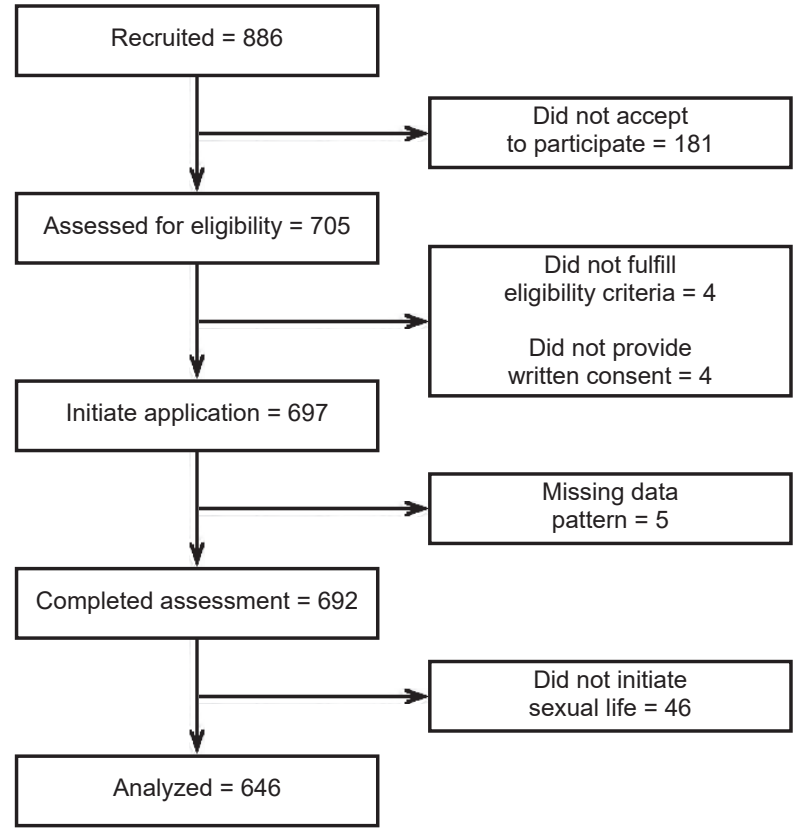

Figure 2. Participants flow chart during Study 2.

reported lack of knowledge of the HIV status of their partners in the past 12 months. Those reporting substance use had a lower relative probability of being married, a greater number of partners, a lower frequency of condom use and less knowledge of the HIV status of their partners (table 2).

\section{Confirmatory Factor Analysis}

Items with a correlation of less than .30 between them were removed. After choosing the items for each model, the following was obtained: attitudes consisted of 4 items $(5,7$, $8,9)$, with an adjustment of $\chi_{\mathrm{S}-\mathrm{B}}^{2}(2)=3.902, p<.001 ; \mathrm{CFI}$ s $=.999 ;$ TLI $_{\mathrm{s}}=.996 ; \mathrm{RMSEA}_{\mathrm{s}}=.037,90 \% \mathrm{CI} \leq .001-.095$; for subjective norms model, a 6-item model was used, with a goodness of fit of $\chi_{\mathrm{S}-\mathrm{B}}^{2}(7)=9.103, p<.245 ; \mathrm{CFI}_{\mathrm{s}}=.999$; $\mathrm{TLI}_{\mathrm{s}}=.998 ; \operatorname{RMSEA}_{\mathrm{s}}=.022,90 \% \mathrm{CI} \leq .001-.056$; while for the self-efficacy model, the model was adjusted by $\chi_{\mathrm{S}-\mathrm{B}}^{2}(25)=$ $65.115, p<.001 ; \mathrm{CFI}_{\mathrm{s}}=.982 ; \mathrm{TLI}_{\mathrm{s}}=.974 ; \mathrm{RMSEA}_{\mathrm{s}}=.050$, $90 \% \mathrm{CI}=.036-.066$, with a total of 9 items (table 3 shows the coefficients and standard errors of each model).

\section{Differential Item Functioning (DIF)}

Figure 1 shows the DIF model for each TPB determinant. After correcting the $p$ values through the FDR values, it was found that item 8 ("Excellent-Terrible") had a value of $p<.05$ for the attitudes model, whereas in the subjective norms model, items 4 ("the opinion of the Church/priest if I decide to use a condom") and 8 ("the opinion of my friends who do not use condoms") had statistically significant values ( $p=.009$ and $p=.006$, respectively). No significant DIF were found in the self-efficacy model (table 3 ). 
Table 2

Participants characteristics

\begin{tabular}{|c|c|c|c|c|}
\hline & \multicolumn{3}{|c|}{ Use of alcohol or drugs in past 30 days } & \multirow{3}{*}{$\begin{array}{l}\text { Statistical } \\
\text { differences }\end{array}$} \\
\hline & $\begin{array}{c}\text { Yes } \\
(n=471)\end{array}$ & $\begin{array}{c}\text { No } \\
(n=171)\end{array}$ & $\begin{array}{c}\text { Total } \\
(n=642)\end{array}$ & \\
\hline & $(\mathrm{DE})$ & (DE) & (DE) & \\
\hline Age & $23.25(3.33)$ & $22.90(2.79)$ & 23.16(3.19) & $t(632)=.22$ \\
\hline Years of education & $14.59(1.30)$ & $14.53(1.18)$ & $14.58(1.16)$ & $t(629)=.56$ \\
\hline & $\mathrm{n}(\%)$ & $\mathrm{n}(\%)$ & $\mathrm{n}(\%)$ & \\
\hline $\begin{array}{l}\text { Gender } \\
\text { Female } \\
\text { Male }\end{array}$ & $\begin{array}{l}248(52.7) \\
223(47.3)\end{array}$ & $\begin{array}{c}115(67.3) \\
56(32.7)\end{array}$ & $\begin{array}{l}363(56.5) \\
279(43.5)\end{array}$ & $\chi^{2}(1)=10.87^{*}$ \\
\hline $\begin{array}{l}\text { Marital status } \\
\text { Married/Free union } \\
\text { Widowed/Divorced } \\
\text { Never married }\end{array}$ & $\begin{array}{c}28(5.9) \\
14(3.0) \\
429(91.1)\end{array}$ & $\begin{array}{c}16(9.4) \\
8(4.7) \\
147(86.0)\end{array}$ & $\begin{array}{c}44(6.9) \\
22(3.4) \\
576(89.7)\end{array}$ & $\chi^{2}(4)=3.35$ \\
\hline $\begin{array}{l}\text { Monthly Income } \\
0-2000 \\
2001-4000 \\
4001-6000 \\
6001-10000 \\
\text { More than } 10000\end{array}$ & $\begin{array}{c}203(43.4) \\
118(25.2) \\
80(17.1) \\
55(11.8) \\
12(2.6)\end{array}$ & $\begin{array}{c}77(45.6) \\
42(24.9) \\
20(11.8) \\
24(14.2) \\
6(3.6)\end{array}$ & $\begin{array}{c}280(44.0) \\
160(25.1) \\
100(15.7) \\
79(12.4) \\
18(2.8)\end{array}$ & \\
\hline Not using condom in last intercourse & $241(37.8)$ & $89(14.0)$ & $330(51.8)$ & $\chi^{2}(1)=.028$ \\
\hline Partner concurrence in last 30 days & $92(19.5)$ & $18(10.6)$ & $110(17.1)$ & $\chi^{2}(1)=6.97^{*}$ \\
\hline $\begin{array}{l}\text { Knowledge of HIV serological status of partner } \\
\text { Always } \\
\text { Not always }\end{array}$ & $\begin{array}{l}151(23.7) \\
317(49.7)\end{array}$ & $\begin{array}{c}53(8.3) \\
117(18.3)\end{array}$ & $\begin{array}{l}204(32.0) \\
306(68.0)\end{array}$ & $\chi^{2}(1)=.068$ \\
\hline
\end{tabular}

Note: ${ }^{*} p<.05 ;{ }^{\text {a }}$ Mexican pesos.

\section{DISCUSSION AND CONCLUSION}

The main aim of this study was to develop an instrument for the Mexican population to measure the determinants of TPB (attitudes, subjective norms and self-efficacy) through a content analysis of the answers to open-ended questions and an item selection procedure and the selection of items from the questionnaires on attitudes (4 items), subjective norms (6 items) and self-efficacy (9 items).

A second objective of the study was to evaluate the DIF caused by substance use. Specific items with this effect were found in the attitudes and subjective norms models. This implies that these items have a specific bias. In people with substance use, this bias increases significantly as substance use rises.

Previous studies have shown that there is a positive relationship between attitudes toward condoms and their use (Álvarez, Villarruel, Zhou \& Gallegos, 2010). However, it has been reported that substance use causes a negative evaluation (Conner et al., 2008; Davis et al., 2015). For example, when people are under the effects of any substance use, they avoid using condoms, because they do not feel the same and it delays ejaculation, causing them to rate condoms as terrible (Maher et al., 2011).
It has also been documented that people are influenced by the opinions or behaviors of their peer group, and are more pressured to have unprotected sex when there are people who use substances in the group (item 8 "The opinion of my friends who do not use condoms") (Sacolo et al., 2013; Selikow, Ahmed, Flisher, Mathews \& Mukoma, 2009).

It has been found that religion is a protective factor for both substance and condom use (Inmaculada, Bermudez, Ramiro \& Buela-Casal, 2014; Valle, Canizales \& Potter, 2010). However, the inverse effect that explains the increase in substance use is due to low religiosity (item 4, "The opinion of the Church/priest if I decide to use a condom") (Ellickson, Collins, Hambarsoomians \& McCaffrey, 2005) has not been studied. This is an area for future research to explain this link in more detail.

Item 11 ("Using a condom even if you have used alcohol or other drugs") did not obtain a significant DIF, contrary to expectations, since a negative link has been found between substance use and self-efficacy in condom use (Bennett \& Bozionelos, 2000; Davis et al., 2015). A probable explanation is that when people who have experimented with condom use are intoxicated, they are more likely to use it correctly and consistently even when they are under 
Table 3

CFA and MIMIC analysis results

\begin{tabular}{|c|c|c|c|c|c|}
\hline Dimensions/ Items & $\beta$ & $\mathrm{SE}_{\beta}$ & Z Value & $\begin{array}{l}\text { DIF Effect } \\
(\beta)\end{array}$ & $\begin{array}{l}\text { DIF adjusted } \\
p \text { value }\end{array}$ \\
\hline \multicolumn{6}{|l|}{ Attitudes } \\
\hline 5. Secure - Dangerous & 1.000 & - & - & -.022 & .050 \\
\hline 7. Unneeded - Needed & -.997 & .074 & $13.472^{*}$ & .002 & .872 \\
\hline 8. Excellent - Poor & 1.142 & .078 & $14.641^{*}$ & .019 & $.020^{*}$ \\
\hline 9. Good - Bad & 1.397 & .099 & $14.111^{*}$ & .001 & .872 \\
\hline \multicolumn{6}{|l|}{ Subjective norms } \\
\hline 2. What my parents think if I decide to use condom & 1.000 & - & - & -.018 & .050 \\
\hline 4. The opinion of the church/priest if a choose to use condom & .858 & .078 & $11.000^{*}$ & -.022 & $.009^{*}$ \\
\hline 5. The approval of the physician on the use of condom & .740 & .062 & $11.935^{\star}$ & .002 & .776 \\
\hline 6. What my Friends think about the use of condoms & 1.262 & .072 & $17.527^{*}$ & .010 & .132 \\
\hline 7. What my family thinks about the use of condoms & 1.251 & .071 & $17.619^{*}$ & .004 & .655 \\
\hline 8. The opinion of my Friends who does not use condoms & 1.133 & .073 & $15.520^{\star}$ & .021 & $.006^{*}$ \\
\hline \multicolumn{6}{|l|}{ Self-efficacy } \\
\hline $\begin{array}{l}\text { 2. Suggest the use of condom with a new partner even when you } \\
\text { are afraid he/she may think you have AIDS }\end{array}$ & 1.000 & - & - & 0.019 & .184 \\
\hline $\begin{array}{l}\text { 3. Stop and put on a condom, even when the amount of sexual } \\
\text { arousal is too high }\end{array}$ & .891 & .055 & $16.200^{*}$ & -.007 & .520 \\
\hline 4. Discuss the use of condom with a new partner before intercourse & .898 & .059 & $15.220^{*}$ & .003 & .737 \\
\hline 5. My ability to suggest the use of condoms with a new partner & .945 & .057 & $16.578^{*}$ & .002 & .737 \\
\hline $\begin{array}{l}\text { 6. Negotiate the use of condom even when a partner does not like } \\
\text { them because she/he prefers "the nature" }\end{array}$ & .819 & .057 & $14.368^{*}$ & -.006 & .520 \\
\hline $\begin{array}{l}\text { 9. Suggest the use of condoms to a new partner even when you } \\
\text { are afraid she/he may thing that I am doing it because I believe } \\
\text { he/she may have a STI or HIV }\end{array}$ & 1.029 & .064 & $16.078^{*}$ & .006 & .520 \\
\hline 10. To be able to say to my partner "no" if we don't have a condom & .914 & .058 & $15.758^{*}$ & -.018 & .090 \\
\hline 11. Use condoms even when I have used alcohol or drugs & .838 & .064 & $13.093^{*}$ & .008 & .520 \\
\hline $\begin{array}{l}\text { 13. Use condoms when I assume that my partner won't infect me } \\
\text { with something }\end{array}$ & .825 & .060 & $13.750^{*}$ & -.009 & .519 \\
\hline
\end{tabular}

the effects of a particular substance (Calsyn, Baldwin, Niu, Crits-Christoph \& Hatch-Maillette, 2011).

There is little evidence of the detection of DIF due to substance use in TPB indicators for condom use, since this is the first study to undertake this type of analysis. There is evidence at the construct level that is not sensitive to the DIF effect, meaning that possibly spurious links may be obtained.

DIF was handled differently in our study from previous research (Conrad, Conrad, Passetti, Funk \& Dennis, 2015) that detects items with significant DIF and subsequently eliminates them. This is because the items did not fit the measurement model, as a result of which only the free DIF indicators were used. This has the advantage that the comparison between groups is easier to interpret. However, the disadvantage of this method is the change in the measurement of the construct, since the items deleted provided key information on the phenomenon studied.
Therefore, as is the case, with various studies (Lewis, Yang, Jacobs \& Fitchett, 2012; Starosta et al., 2015), a DIF analysis was conducted to identify the items that operated differently between peer groups to determine the reason why the item is being modified by an observable variable (e.g. substance use). According to the authors, items with DIF open the door to future research, due to the importance of evaluating how indicators behave with a population with a particular trait.

It is important to mention that during the evaluation of the measurement models, detection and handling of items with DIF is substantial. There are alternatives ranging from the deletion of the item from the scale to the inclusion of the variable that causes DIF in the model. In both cases, the objective is to balance the scores in order to prevent the indicators from providing inflated results in the group. This in turn leads to a loss of accuracy in the evaluation of the con- 
struct and therefore unreliable results (Starosta et al., 2015). Accordingly, if an item with DIF is detected, the researcher must decide whether to delete the item or to handle it with caution in order to prevent results from being altered by a bias in the measurement of the indicators.

Limitations considered in the study include: marital status assessment, since asking whether a person has "Ever been married" fails to provide information on the current relationship or its duration. The link between substance use and sexual behavior in states of intoxication, measured by the number of days of use of any substance, fails to discriminate between the days when substances were used and when they were not. This is particularly important because the study was conducted on a non-clinical population (college students), which is why it is essential to conduct studies where the amounts of the substance used are measured in order to observe a direct relationship between the two variables. Another limitation was the fact that sexual orientation was not included in the analysis of the DIF. This has been a concern in previous studies (Starosta et al., 2015) since people with a predominantly homosexual or bisexual orientation may respond differently from heterosexual men and women. This issue should be considered in future studies evaluating the DIF caused by sexual preferences. Another constraint was the sample size, which made it impossible to perform more complex analyses of DIF. Interactions were observed between substance use and sex in the indicators of TCP determinants in condom use. A larger sample size would be required to improve the accuracy of this analysis.

In conclusion, the detection of DIF in the evaluation of measurement models is a substantial need in the accurate assessment of psychosocial constructs. This is the case of substance use in TCP indicators, where bias was detected in the measurement of indicators. These could be areas of opportunity where prevention programs could have an impact on increasing condom use and controlling HIV/AIDS.

\section{Funding}

This study was funded by The Sectoral Fund for Research in Health and Social Security (FOSISS) project number 262500 awarded to RMN. During this study, LVG and RSD received funding from The National Council of Science and Technology (CONACYT) through a doctoral grant no. 383294 (LVG) and a master's grant no. 392401 (RSD).

\section{Conflict of interests}

The authors declare they have no conflict of interest.

\section{REFERENCES}

Ajzen, I. (1991). The theory of planned behavior. Organizational Behavior and Human Decision Processes, 50(2), 179-211. http://doi.org/10.1016/0749-5978(91) 90020-T.

Ajzen, I., \& Fishbein, M. (1980). Understanding Attitudes and Prediciting Social Behaviour. Englewood Cliffs: Prentice Hall.
Albarracín, D., Johnson, B. T., Fishbein, M., \& Muellerleile, P. a. (2001). Theories of reasoned action and planned behavior as models of condom use: a meta-analysis. Psychological Bulletin, 127(1), 142-161. http://doi.org/10.1037/00332909.127.1.142

Alvarez, C., Villarruel, A. M., Zhou, Y., \& Gallegos, E. (2010). Predictors of condom use among Mexican adolescents. Research and Theory for Nursing Practice, 24(3), 187-196. http://doi.org/10.1891/1541-6577.24.3.187

Andrew, B. J., Mullan, B. A., de Wit, J. B. F., Monds, L. A., Todd, J., \& Kothe, E. J. (2016). Does the Theory of Planned Behaviour Explain Condom Use Behaviour Among Men Who have Sex with Men? A Meta-analytic Review of the Literature. AIDS and Behavior, 1-11. http://doi.org/10.1007/s10461-016-1314-0

Armitage, C. J., \& Conner, M. (2001). Efficacy of the Theory of Planned Behaviour: a meta-analytic review. The British Journal of Social Psychology / the British Psychological Society, 40(Pt 4), 471-499. http://doi.org/10.1348/014466601164939

Beauducel, A., \& Herzberg, P. Y. (2006). On the Performance of Maximum Likelihood Versus Means and Variance Adjusted Weighted LEast Squares Estimation in CFA. Structural Equation Modeling, 13(2), 204-228. http://doi.org/10.1207/ s15328007sem 1302

Benjamini, Y., \& Hochberg, Y. (1995). Controlling the False Discovery Rate: A Practical and Powerful Approach to Multiple Testing. Journal of the Royal Statistical Society. Series B (Methodological), 57(1), 289-300. http://doi.org/10.2307/ 2346101

Bennett, P., \& Bozionelos, G. (2000). The theory of planned behaviour as predictor of condom use: A narrative review. Psychology, Health \& Medicine, 5(3), 307-326. http://doi.org/10.1080/713690195

Calsyn, D. A., Baldwin, H., Niu, X., Crits-Christoph, P., \& Hatch-Maillette, M. A. (2011). Sexual risk behavior and sex under the influence: An event analysis of men in substance abuse treatment who have sex with women. American Journal on Addictions, 20(3), 250-256. http://doi.org/10.1111/j.15210391.2011.00123.x

Centers for Disease Control and Prevention [CDC]. (2014). Sexually Transmitted Disease Surveillance 2013.

Centro Nacional para la prevención y el control del VIH/SIDA [CENSIDA]. (2016). "Vigilancia Epidemiológica de casos de VIH/SIDA en México Registro Nacional de Casos de SIDA Actualización al 2do. Trimestre de 2016".

Conner, M., Sutherland, E., Kennedy, F., Grearly, C., \& Berry, C. (2008). Impact of alcohol on sexual decision making: Intentions to have unprotected sex. Psychology \& Health, 23(8), 909-934. http://doi.org/10.1080/08870440701596551

Conrad, K. M., Conrad, K. J., Passetti, L. L., Funk, R. R., \& Dennis, M. L. (2015). Validation of the Full and Short-Form Self-Help Involvement Scale Against the Rasch Measurement Model. Evaluation Review, 39(4), 395-427. http://doi.org/ 10.1177/0193841X15599645

Cribbie, R. a. (2007). Multiplicity Control in Structural Equation Modeling. Structural Equation Modeling: A Multidisciplinary Journal, 14(1), 98-112. http://doi. org/10.1207/s15328007sem1401_5

Crosby, R. A., Charnigo, R. A., Weathers, C., Caliendo, A. M., \& Shrier, L. A. (2012). Condom effectiveness against non-viral sexually transmitted infections: a prospective study using electronic daily diaries. Sexually Transmitted Infections, 88(7), 484-9. http://doi.org/10.1136/sextrans-2012-050618

Davis, K. C., Jacques-Tiura, A. J., Stappenbeck, C. A., Danube, C. L., Morrison, D. M., Norris, J., \& George, W. H. (2015). Men's Condom Use Resistance: Alcohol Effects on Theory of Planned Behavior Constructs. Health Psychology, 35(2), 178-186. http://doi.org/10.1037/hea0000269

Donenber, G. R., Emerson, E., Bryant, F. B., Wilson, H., \& Weber-Shifrin, E. (2001). Understanding AIDS-Risk Behavior Among Adolescents in Psychiatric Care: Links to Psychopathology and Peer Relationships. Journal of the American Academy of Child \& Adolescent Psychiatry, 40(6), 642-653. http://doi. org/10.1097/00004583-200106000-00008

Donovan, D. M., Bigelow, G. E., Brigham, G. S., Carroll, K. M., Cohen, A. J., Gardin, J. G. et al. (2012). Primary outcome indices in illicit drug dependence treatment research: systematic approach to selection and measurement of drug use end-points in clinical trials. Addiction, 107(4), 694-708. http://doi.org/10.1111/ j.1360-0443.2011.03473.x

Ellickson, P. L., Collins, R. L., Hambarsoomians, K., \& McCaffrey, D. F. (2005). Does alcohol advertising promote adolescent drinking? Results from a longi- 
tudinal assessment. Addiction, 100(2), 235-246. http://doi.org/10.1111/j.13600443.2005.00974.x

Encuesta Nacional de Salud y Nutricion [ENSANUT]. (2012). Resultados Nacionales. Mexico: Cuernavaca.

Enders, C. K., \& Bandalos, D. L. (2001). The Relative Performance of Full Information Maximum Likelihood Estimation for Missing Data in Structural Equation Models. Structural Equation Modeling: A Multidisciplinary Journal, 8(3), 430-457. http://doi.org/10.1207/S15328007SEM0803_5

Fishbein, M. (1980). A theory of reasoned action: some applications and implications. Nebraska Symposium on Motivation. Nebraska Symposium on Motivation, 27, 65-116. Retrieved from http://www.ncbi.nlm.nih.gov/pubmed/7242751

Fishbein, M., \& Ajzen, I. (1975). Belief, Attitude, Intention, and Behavior: An Introduction to Theory and Research. Reading, MA: Addison-Wesley. http://doi. org/10.1017/CBO9781107415324.004

Fishbein, M., \& Ajzen, I. (2010). Predicting and changing behaviour: The reasoned action approach. New York: Psychology Press. http://doi. org $/ 10.4324 / 9780203937082$

Francis, A. J. J., Eccles, M. P. M., Johnston, M., Walker, A., Grimshaw, J., Foy, R., ... Francis, J. (2004). Constructing questionnaires based on the theory of planned behaviour: a manual for health services researchers. Direct. Newcastle, UK. http://doi.org/0-9540161-5-7

Hu, L., \& Bentler, P. M. (1999). Cutoff criteria for fit indexes in covariance structure analysis: Conventional criteria versus new alternatives. Structural Equation Modeling: A Multidisciplinary Journal, 6(1), 1-55. http://doi. org $/ 10.1080 / 10705519909540118$

Inmaculada, T., Bermudez, M. P., Ramiro, M. T., \& Buela-Casal, G. (2014). Creencias religiosas y actitudes hacia el uso del preserVatiVo en adolescentes peruanos. Revista Mexicana de Psicología, 31(1), 41-49.

Instituto Nacional de las Mujeres[INMUJERES]. (2012). Enfermedades de transmisión sexual y VIH-SIDA.

Krippendorff, K. (1990). Metodología del análisis de contenido. (Paidos, Ed.). España.

Lewis, T. T., Yang, F. M., Jacobs, E. A., \& Fitchett, G. (2012). Racial/ethnic differences in responses to the everyday discrimination scale: a differential item functioning analysis. American Journal of Epidemiology, 175(5), 391-401. http:// doi.org/10.1093/aje/kwr287

Maher, L., Phlong, P., Mooney-Somers, J., Keo, S., Stein, E., Couture, M. C., \& Page, K. (2011). Amphetamine-type stimulant use and HIV/STI risk behaviour among young female sex workers in Phnom Penh, Cambodia. The International Journal on Drug Policy, 22(3), 203-9. http://doi.org/10.1016/j.drugpo.2011.01.003

Malcolm, S., Huang, S., Cordova, D., Freitas, D., Arzon, M., Jimenez, G. L., ... Prado, G. (2013). Predicting condom use attitudes, norms, and control beliefs in Hispanic problem behavior youth: the effects of family functioning and parent-adolescent communication about sex on condom use. Health Education \& Behavior, 40(4), 384-391. http://doi.org/10.1177/1090198112440010

Miles, J. N. V, Marshall, G. N., \& Schell, T. L. (2008). Spanish and English versions of the PTSD Checklist-Civilian version (PCL-C): testing for differential item functioning. Journal of Traumatic Stress, 21(4), 369-76. http://doi.org/10.1002/ jts. 20349

Muthén, B., \& Kaplan, D. (1985). A comparison of some methodologies for the factor analysis of non-normal Likert variables. British Journal of Mathematical and Statistical Psychology, 38(2), 171-189. http://doi.org/10.1111/j.2044-8317.1985. tb00832.x
Muthén, L. K., \& Muthén, B. O. (2002). How to Use a Monte Carlo Study to Decide on Sample Size and Determine Power. Structural Equation Modeling: A Multidisciplinary Journal, 9(4), 599-620. http://doi.org/10.1207/S15328007SEM0904_8

Noar, S. M. (2006). A 10-Year Retrospective of Research in Health Mass Media Campaigns: Where Do We Go From Here? Journal of Health Communication, 11(1), 21-42. http://doi.org/10.1080/10810730500461059

Prati, G., Mazzoni, D., \& Zani, B. (2014). Perceived behavioural control, subjective norms, attitudes and intention to use condom: A longitudinal cross-lagged design. Psychol Health, 29(10), 1119-1136. http://doi.org/10.1080/08870446.20 14.913043

Rich, A., Mullan, B. A., Sainsbury, K., \& Kuczmierczyk, A. R. (2014). The role of gender and sexual experience in predicting adolescent condom use intentions using the theory of planned behaviour. The European Journal of Contraception \& Reproductive Health Care, 19(4), 295-306. http://doi.org/10.3109/1362518 7.2014.917624

Robles-Montijo, S., \& Díaz-Loving, R. (2011). Validación de la Encuesta Estudiantil sobre salud sexual (EESS). (F. de E. S. Iztacala, Ed.). México.

Rodríguez-Pérez, V., Valencia-Flores, M., Reyes-Lagunes, I., \& Lara-Muñoz, M. del C. (2013). Adaptación y validación psicométrica del Cuestionario de Consecuencias Funcionales del Dormir (Functional Outcomes Sleep Questionnaire [FOSQ]) en habitantes de la Ciudad de México. Salud Mental, 36(4), 307-313.

Sacolo, H. N., Chung, M.-H., Chu, H., Liao, Y.-M., Chen, C.-H., Ou, K.-L., ... Chou, K.-R. (2013). High risk sexual behaviors for HIV among the in-school youth in Swaziland: a structural equation modeling approach. PloS One, 8(7), e67289. http://doi.org/10.1371/journal.pone.0067289

Satorra, A., \& Bentler, P. (2001). A scaled difference chi-square test statistic for moment structure analysis. Psychometrika, 66(4), 507-514. http://doi.org/10.1007/ bf02296192

Selikow, T.-A., Ahmed, N., Flisher, A. J., Mathews, C., \& Mukoma, W. (2009). I am not "umqwayito": a qualitative study of peer pressure and sexual risk behaviour among young adolescents in Cape Town, South Africa. Scandinavian Journal of Public Health, 37 Suppl 2(2 suppl), 107-12. http://doi. org/10.1177/1403494809103903

Starosta, A. J., Berghoff, C. R., \& Earleywine, M. (2015). Factor structure and gender stability in the multidimensional condom attitudes scale. Assessment, 22(3), 374-84. http://doi.org/10.1177/1073191114547887

Tyson, M., Covey, J., \& Rosenthal, H. E. S. (2014). Theory of planned behavior interventions for reducing heterosexual risk behaviors: A meta-analysis. Health Psychology, 33(12), 1454-1467. http://doi.org/10.1037/hea0000047

United Nations Programme on HIV and AIDS [UNAIDS]. (2014). Global statistics 2014.

United Nations Programme on HIV and AIDS [UNAIDS]. (2015). Position statement on condoms and the prevention of HIV, other sexually transmitted infections and unintended pregnancy. Retrieved from http://www.unaids.org/es/resources/ presscentre/featurestories/2015/july/20150702_condoms_prevention

Valle, E. D. V., Canizales, G. M., \& Potter, J. E. (2010). Religión e iniciación sexual premarital en México. Revista Latinoamericana de Población, 4(7), 7-30.

Vasilenko, S. A., \& Lanza, S. T. (2014). Predictors of multiple sexual partners from adolescence through young adulthood. Journal of Adolescent Health, 55(4), 491-497. http://doi.org/10.1016/j.jadohealth.2013.12.025

Yzer, M. C. (2012). The Integrative Model of Behavior Prediction as a Tool for Designing Health Messages, 21-40. 


\section{Appendix 1 Original items in Spanish}

Questionnaire A1. Attitudes

\begin{tabular}{|c|c|c|c|c|c|c|c|c|c|}
\hline 1. & Agradable & 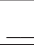 & - & - & - & - & - & - & Desagradable \\
\hline 2. & Tonto & $=$ & $=$ & $=$ & $=$ & $=$ & $=$ & $=$ & Inteligente \\
\hline 3. & Divertido & $\ldots$ & - & - & - & - & - & - & Aburrido \\
\hline 4. & Difícil & $=$ & - & - & $=$ & - & - & - & Fácil \\
\hline 5. & Seguro & $=$ & - & - & $=$ & - & - & - & Peligroso \\
\hline 6. & Responsable & $=$ & - & - & - & - & - & - & Irresponsable \\
\hline 7. & Innecesario & - & - & - & - & - & - & - & Necesario \\
\hline 8. & Excelente & $=$ & - & - & - & - & - & - & Pésimo \\
\hline 9. & Bueno & $=$ & - & $=$ & $=$ & - & - & - & Malo \\
\hline 10. & Incómodo & $=$ & - & 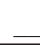 & $=$ & - & - & - & Cómodo \\
\hline
\end{tabular}

\section{Questionnaire A2. Subjective norms}

$(0=$ Sin importancia; 1 = Algo importante; $2=$ Medianamente importante; $3=$ Muy importante $)$

\begin{tabular}{|c|c|c|c|c|c|}
\hline 1. & Qué mi pareja esté de acuerdo que utilicemos condón cuando vayamos a tener relaciones sexuales & 0 & 1 & 2 & 3 \\
\hline 2. & Lo que opinen mis padres si decido utilizar condón & 0 & 1 & 2 & 3 \\
\hline 3. & La opinión de mi pareja sexual si decido utilizar condón & 0 & 1 & 2 & 3 \\
\hline 4. & La opinión de la iglesia/sacerdote si decido utilizar condón & 0 & 1 & 2 & 3 \\
\hline 5. & La aprobación del médico sobre el uso del condón & 0 & 1 & 2 & 3 \\
\hline 6. & Lo que opinen mis amigos si decido utilizar condón & 0 & 1 & 2 & 3 \\
\hline 7. & Lo que opinen mis familiares si decido utilizar condón & 0 & 1 & 2 & 3 \\
\hline 8. & La opinión de mis amigos que no utilizan condón & 0 & 1 & 2 & 3 \\
\hline
\end{tabular}

\section{Questionnaire A3. Self-efficacy}

$(0=$ Totalmente Inseguro: 1 = Algo seguro; $2=$ Muy seguro; $3=$ Totalmente seguro $)$

\begin{tabular}{|c|c|c|c|c|c|}
\hline 1. & $\begin{array}{l}\text { Buscar o conseguir un condón si se me da la oportunidad de tener relaciones sexuales con alguien que me } \\
\text { atrae y es posible que no se presente otra ocasión. }\end{array}$ & 0 & 1 & 2 & 3 \\
\hline 2. & $\begin{array}{l}\text { Sugerir el uso de condón con una nueva pareja sexual aunque tengas miedo que piense que padeces alguna } \\
\text { Enfermedad de Transmisión Sexual o SIDA. }\end{array}$ & 0 & 1 & 2 & 3 \\
\hline 3. & Poder detenerme y ponerme un condón, incluso cuando el grado de excitación es muy alto. & 0 & 1 & 2 & 3 \\
\hline 4. & Discutir el uso del condón con una pareja sexual antes de tener sexo. & 0 & 1 & 2 & 3 \\
\hline 5. & Mi capacidad para sugerir el uso de condones con una nueva pareja sexual. & 0 & 1 & 2 & 3 \\
\hline 6. & Negociar el uso de condón aunque a tu pareja sexual no le guste, ya que prefiere lo natural. & 0 & 1 & 2 & 3 \\
\hline 7. & $\begin{array}{l}\text { Poder conseguir un condón si mis amigos me presionan a tener relaciones con alguien que acabo de con- } \\
\text { ocer. }\end{array}$ & 0 & 1 & 2 & 3 \\
\hline 8. & Poder utilizar un condón si mi pareja me dice que quiere tener un bebé a pesar que yo no quiera. & 0 & 1 & 2 & 3 \\
\hline 9. & $\begin{array}{l}\text { Sugerir el uso de condón a una nueva pareja sexual aunque piense que lo hago porque creo que tiene una } \\
\text { Enfermedad de Transmisión Sexual o SIDA. }\end{array}$ & 0 & 1 & 2 & 3 \\
\hline 10. & Poder decirle "no" a mi pareja sexual si no tenemos un condón a la mano. & 0 & 1 & 2 & 3 \\
\hline 11. & Utilizar condón aunque haya consumido alcohol u otras drogas. & 0 & 1 & 2 & 3 \\
\hline 12. & Usar condón sin importar que reduzca el placer sexual. & 0 & 1 & 2 & 3 \\
\hline 13. & Utilizar condón cuando asumo que mi pareja sexual no me va a contagiar de algo. & 0 & 1 & 2 & 3 \\
\hline 14. & Mi capacidad de poner un condón correctamente. & 0 & 1 & 2 & 3 \\
\hline 15. & Comprar condones sin sentirse avergonzado(a). & 0 & 1 & 2 & 3 \\
\hline 16. & Recordar llevar un condón conmigo por si lo necesito. & 0 & 1 & 2 & 3 \\
\hline
\end{tabular}

